\title{
Intervention studies of cotton steaming to reduce biological effects of cotton dust
}

\author{
J.A. MERCHAN T'1 , J. C. LUMSDEN ${ }^{2}$, K. H. KILBURN ${ }^{3}$, \\ W. M. O'FALLON ${ }^{4}$, K. COPELAND ${ }^{4}$, V. H. GERMINO ${ }^{1}$, W. N. MCKENZIE \\ D. BAUCOM ${ }^{2}$, P. CURRIN 2 , and J. STILMAN ${ }^{2}$
}

University of North Carolina, Chapel Hill, North Carolina ${ }^{1}$; North Carolina State Board of Health, Raleigh, North Carolina ${ }^{2}$; University of Missouri, Columbia, Missouri ${ }^{3}$; and Duke University Medical Center, Durham, North Carolina, USA ${ }^{4}$

\begin{abstract}
Merchant, J. A., Lumsden, J. C., Kilburn, K. H., O'Fallon, W. M., Copeland, K., Germino, V. H., McKenzie, W. N., Baucom, D., Currin, P., and Stilman, J. (1974). British Journal of Industrial Medicine, 31, 261-274. Intervention studies of cotton steaming to reduce biological effects of cotton dust. Previous exposure chamber studies had suggested that steaming cotton could reduce significantly the levels and the biological effects of cotton dust. Therefore an intervention study using a high capacity steamer was designed to test the effectiveness of this process in a single cotton mill. The mill population was surveyed and dust sampling was completed prior to intervention with steamed cotton. A panel of 62 byssinotics and heavily exposed workers was selected to serve as a test panel while steamed cotton was introduced to the mill. Following the introduction of adequately steamed cotton the mean Monday decrement in forced expired volume in one second among panel members was significantly reduced to half that observed during control trials. Dust levels were also significantly reduced in the initial opening and picking processes but increased significantly in later processes. Re-evaluation of the mill population by work area suggested some improvement in expiratory flow per milligram of dust exposure but a progression in symptoms of byssinosis and bronchitis in later mill processes. It is suggested that steaming may have resulted in removal of some bronchoconstricting property of cotton dust, but that binding of fine dust to the fibre may also occur, resulting in delayed release of fine dust particles. The implications of these observations on environmental control are discussed.
\end{abstract}

Over a decade ago Schilling observed that the lack of control of byssinosis in the cotton textile industry stemmed primarily from the cost and inadequacy of local exhaust systems in controlling cotton dust, and he suggested a more basic approach, such as washing cotton (Schilling et al., 1964). Subsequent surveys in Britain (Molyneux and Tombleson, 1970; Fox, Tombleson, Watt, and Wilkie, 1973) and the United States (Bouhuys et al., 1969; Zuskin et al., 1969; Schrag and Gullet, 1970; Merchant et al., 1972; Merchant et al., 1973b) have shown that byssinosis is still prevalent, thus attesting to the accuracy of Schilling's observation. It is also clear that byssinosis affects a substantial number of workers at relatively low dust levels (Merchant et al., 1973c). The objective of a more basic approach, therefore, is to control low levels of respirable dust using methods that are technically feasible and relatively inexpensive so as to encourage environmental control.

As described in a previous communication (Merchant et al., 1973a), experimental trials were conducted in a human exposure chamber (experimental carding room) to test the effectiveness and feasibility of washing and steaming cotton. Of the methods tested, washing most completely removed biological activity, but in manufacturing trials the 
cotton was found to spin poorly. Steaming cotton under pressure in an autoclave was nearly as efficient in reducing dust levels and biological activity as was washing but could not be adapted easily or economically to the manufacturing process. Steaming cotton without pressure in a 'pipe steamer' was found to be nearly as effective as autoclaving and could be integrated into manufacturing without impairing cotton spinning qualities. A high-capacity steamer was designed based on the 'pipe steamer' model. When cotton processed through this steamer was tested for biological activity in the exposure chamber, previous observations were confirmed.

Therefore, an intervention trial with cotton steamed by this method was designed to test the effectiveness of steaming cotton in reducing dust levels and biological effects throughout a single cotton spinning mill. The mill selected for this study had been the site of previous exposure chamber trials and had been studied prospectively for two years. The mill processed uniformly coarse, lowcount cotton resulting in high dust levels and a correspondingly high prevalence of byssinosis which had ranged from over $40 \%$ in preparation areas to $20 \%$ in winding and twisting areas (Merchant, 1970). Because of the ineffectiveness of conventional exhaust systems in handling the heavy dust load, this mill needed better environmental control in all work areas and was therefore thought to be well suited for a steaming intervention study.

\section{Methods}

The mill and raw materials

The mill was located in a small tobacco town in eastern North Carolina where atmospheric pollution was considered negligible. It spun uniformly strict low middling cotton from western Oklahoma and Texas with an average count of 6 and an average fibre length of $15 / 16$ inches. Rayon was blended with cotton prior to the picking process and at the time of the baseline studies

TABLE 1

Testing Sequence of Intervention Study

\begin{tabular}{|c|c|c|c|c|}
\hline $\begin{array}{c}\text { Trial } \\
\text { number }\end{array}$ & $\begin{array}{c}\text { Study } \\
\text { population }\end{array}$ & Tests performed & Cotton processed & Comments \\
\hline $\begin{array}{l}\text { Baseline } \\
\text { studies }\end{array}$ & $\begin{array}{l}\text { All operatives } \\
(372)\end{array}$ & $\begin{array}{l}\text { Questionnaire, pulmonary } \\
\text { function before and after } \\
\text { exposure, dust levels }\end{array}$ & $\begin{array}{l}\text { Unsteamed, } \\
\text { SLM cotton }\end{array}$ & $\begin{array}{l}\text { Blended with } 17 \% \text { rayon by } \\
\text { weight at picking process }\end{array}$ \\
\hline $\begin{array}{l}\text { Baseline } \\
\text { studies } \\
\text { repeated }\end{array}$ & Test panel (62) & $\begin{array}{l}\text { Pulmonary function before } \\
\text { and after exposure, dust } \\
\text { levels }\end{array}$ & As above & \\
\hline 1 & Test panel (58) & As above & $\begin{array}{l}15 \% \text { of SLM cotton } \\
\text { steamed }\end{array}$ & \\
\hline 2 & Test panel (56) & As above & $\begin{array}{l}50 \% \text { of SLM cotton } \\
\text { steamed }\end{array}$ & \\
\hline 3 & Test panel (48) & As above & $\begin{array}{l}75 \% \text { of SLM cotton } \\
\text { steamed }\end{array}$ & \\
\hline 4 & Test panel (52) & As above & $\begin{array}{l}100 \% \text { of SLM cotton } \\
\text { steamed }\end{array}$ & $\begin{array}{l}\text { Steam volume reduced to } \\
800 \mathrm{lb} / \mathrm{hr}\end{array}$ \\
\hline 5 & Test panel (50) & As above & As above & As above \\
\hline 6 & Test panel (51) & As above & As above & $\begin{array}{l}\text { Steam volume increased to } \\
950 \mathrm{lb} / \mathrm{hr}\end{array}$ \\
\hline 7 & Test panel (48) & As above & As above & As above \\
\hline 8 & Test panel (43) & As above & As above & $\begin{array}{l}\text { Blended } 25 \% \text { rayon by weight, } \\
\text { further controls placed on } \\
\text { steamers, steam volume } 950 \\
\text { lb/hr }\end{array}$ \\
\hline 9 & $\begin{array}{l}\text { All operatives } \\
\quad(287)\end{array}$ & $\begin{array}{l}\text { Questionnaire, pulmonary } \\
\text { function before and after } \\
\text { exposure, dust levels }\end{array}$ & As above & As above \\
\hline
\end{tabular}

SLM $=$ strict low middling

Numbers in parentheses are the number of operatives participating 
(1972) constituted $17 \%$ of the yarn by weight. A new cotton crop of the same quality was phased into production beginning before the seventh panel trial (Table 1) but was not fully into production when the study ended. After the seventh panel trial the percentage of rayon was increased by $25 \%$ by weight.

Conventional opening, blending, and picking machinery without exhaust ventilation was used in the opening and picking area which was partitioned from the cardroom and had an independent ventilation system. Highspeed cards with crush-rolls were exhausted to woven nylon bags located within the cardroom. The drawing frames, roving frames, and the spinning frames were all located in one large work area together with the carding machines. The winding and twisting area was located on a separate level and had an independent ventilation system. The entire mill was air-conditioned and used conventional pleated media filters to remove large dust and lint.

\section{Study population and selection of test panel}

The mill population was two-thirds white and one-third black. Most employees were from rural areas and were native to North Carolina. The mill operated on a threeshift schedule; the first shift began at 8 am and ran until $4 \mathrm{pm}$, the second shift until 12 midnight, and the third shift until $8 \mathrm{am}$. The mill operated five or six days a week, depending on production demands. At the beginning of the study the mill operated on a five-day work week with a two-day or 64-hour weekend. After the first steaming trial the mill moved to a six-day work week with a oneday or 40-hour weekend.

Preceding intervention with steamed cotton all manufacturing employees who had participated in previous mill studies as well as new employees were asked to participate in a survey which included a questionnaire, pulmonary function testing before and after exposure, and dust sampling. From questionnaire results those with a history of byssinosis by Schilling's criteria (Roach and Schilling, 1960) were identified and their mean decrement in forced expired volume in one second $\left(\mathrm{FEV}_{1.0}\right)$ and its standard deviation was calculated. With this information it was determined that a test panel of 60 such individuals would be needed to detect with $95 \%$ confidence a $100 \mathrm{ml}$ improvement in $\mathrm{FEV}_{\mathbf{1 . 0}}$ decrement. Since it was desirable to include all byssinotic workers but to limit the panel to those working the first or second shift, a panel of 63 was selected in the following manner. All those with any grade of byssinosis working on the first and second shifts were included. Since most of those working in opening and picking areas were thereby selected and others had large decrements in $\mathrm{FEV}_{1 \cdot 0}$ all employees in these two areas were included. To bring the number to at least 60 , every third employee in the carding area was randomly selected. After the proposed trials were explained to the 63 workers so selected, one declined to participate, leaving 62 . The trial testing sequence is detailed in Table 1.

\section{The steamer}

The high-capacity steamer was designed and developed by Burlington Industries, Inc. and installed in their Smithfield Spinning Plant. Cotton bales were opened adjacent to the steamer and fed through blending machines to a conveyor. From the conveyor the fibres were fed pneumatically to the top of the steamer where two reciprocating arms packed the cotton into a rectangular steaming chamber. Two rolls at the bottom of the chamber supported the column of cotton and controlled transit time. The cotton was removed from the bottom of the column by a high-speed opening roll and then conveyed pneumatically to a bale press where it was rebaled for later use. Low-pressure steam was introduced halfway down the column. After passing through the cotton, steam was exhausted from the top and bottom of the column.

Several technical problems were encountered during the course of these trials. Increased heat load during the first two trials required an increased air-conditioning capacity plus local exhaust in the vicinity of the steamers. A second problem was that of choking of damp cotton at the bottom of the steamers. This resulted in frequent delays and encouraged the operator to adjust the steam volume to a point where this would not occur. Following a third trial it was observed on several occasions that the cotton discharged from the steamer was warm but not damp. Steam volume was found to be reduced and poorly controlled for cotton steamed for trials 4 and 5 . It was also discovered by the designers that there was a wide variation in transit time of cotton through the steaming zone and that there was uneven distribution of steam in cotton within the steaming column. Therefore, prior to trial 6, the cotton discharging assembly on the bottom of the steamer was modified and controls were applied to make the transit of cotton through the steaming zone uniformly of five minutes' duration. This allowed the steam volume to be increased to between 900 and 1000 $\mathrm{lb} / \mathrm{hr}$ with little difficulty with choking. Following trial 7 , further controls were applied to maintain a uniform transit time. Uneven distribution of steam within the cotton plug remained unresolved.

\section{Survey methods and definitions}

The questionnaire used in the two plantwide surveys is the British Medical Research Council Questionnaire for Respiratory Symptoms (MRC Committee on Aetiology of Chronic Bronchitis, 1960) as modified for byssinosis (Roach and Schilling, 1960) to which were added questions regarding smoking history and occupational exposure. ${ }^{1}$ All interviewing was done by three interviewers; J.A.M. asked all questions dealing with respiratory symptoms during both plantwide surveys. Demographic information and smoking history were recorded by V.H.G. during the first plantwide survey (1972) and by W.N.M. during the second (1973).

Based on questionnaire responses, the following operational definitions were adopted for this survey.

Byssinosis was defined as:

Grade 1/2: Occasional chest tightness or breathing difficulty on Monday or Monday cough

Grade 1: Chest tightness or breathing difficulty every Monday

${ }^{1}$ See NAPS document 02047 for 8 pages of supplementary material; order from ASIS/NAPS, c/o Microfiche Publications, 305 E. 46th St., New York, N.Y. 10017. Remit in advance for each NAPS accession number $\$ 1.50$ for microfiche or $\$ 5.00$ for photocopies. Make cheques payable to Microfiche Publications. 
Grade 2: Chest tightness or breathing difficulty on Monday and other work days

Bronchitis was defined as:

Grade 1: Production of phlegm on most days for as much as three months a year, but less than two years

Grade 2: Production of phlegm on most days for as much as three months each year for two or more years

Grade 3: Production of phlegm on most days for as much as three months each year for two or more years plus a chest illness with increased cough and phlegm lasting three weeks or more, or a chest illness with increased phlegm requiring staying off work, indoors, at home or in bed as long as one week.

Dyspnoea grade $3+$ was diagnosed in workers who became breathless walking with other people at an ordinary pace on the level, stopping for breath when walking at their own pace on the level, or breathless on washing or dressing.

Smoking habits were defined as:

Never smoked: Subject never smoked as much as one cigarette a day, or one ounce of tobacco a month, for as long as one year

Current cigarette smoker: At the time of interview smoked at least one cigarette per day and had been doing so up to one month before the interview

Cigar and pipe smoker: At the time of interview smoked $1 \mathrm{oz}$ of tobacco per month or had been doing so up to one month before the interview

Mixed cigarette, pipe or cigar smoker: Categorized as current cigarette smoker

Ex-smoker: Previously smoked cigarettes, cigars or pipe but had not smoked any of the three for one month prior to the survey

Pack year: Smoking one pack of cigarettes per day for one year constitutes one pack year.

Workers were assigned to four primary work areas as follows:

Opening and picking: those with a full-time assignment working in the area where the processes of opening, blending or picking were located

Carding: those with full-time assignments working in the area where the carding, drawing or roving processes were located

Spinning: those with full-time assignments working in the spinning area

Winding and twisting: those with full-time assignments working in the winding and twisting areas.

\section{Pulmonary function}

All pulmonary function tests were conducted with three waterless wedge spirometers ${ }^{1}$. The mean of the two highest of four or more $\mathrm{FEV}_{1.0}$ before and after six hours of dust exposure was used. All workers were tested on Monday in the hour before work and returned to the same spirometer for the post-exposure $\mathrm{FEV}_{1 \cdot 0}$. Change in mean $\mathrm{FEV}_{1.0}$ over six hours $\left(\triangle \mathrm{FEV}_{1.0}\right)$ was calculated.

1Jones Pulmonor II, Jones Medical Instrument Corporation, Oakbrook, Illinois, USA.

\section{Dust sampling}

Dust sampling was done with 25 vertical elutriator cotton dust samplers using the methods described by Lynch (1970). Six samplers were located in the opening and picking area, 10 in carding, five in spinning, and four in winding and twisting. The samplers were attached to support columns at approximately 50 -foot intervals with inlets placed in the breathing zone. Sampling was begun on Monday morning and continued through Tuesday, by which time six 4-8-hour samples had been collected on each sampler. The elutriators were left in their respective positions throughout the survey. Samples were collected on desiccated $37 \mathrm{~mm}$ vinyl metrical filters which were redesiccated prior to being weighed on a Cahn Electrobalance.

\section{Statistical analyses}

Data collected during the two trials prior to intervention with steamed cotton were used as control data against which to test results obtained during the steaming trials. Because dust levels varied between trials and it was desirable to demonstrate the 'biological activity' per $\mathrm{mg} / \mathrm{m}^{3}$ of dust, all $\triangle \mathrm{FEV}_{1.0}$ were adjusted to $1 \mathrm{mg} / \mathrm{m}^{2}$ by dividing $\triangle F E V_{1.0}$ by the dust level measured within each work area at the time of each trial. $\triangle F E_{1.0}$ per $\mathrm{mg} / \mathrm{m}^{3}$ for surviving panel members for each trial was calculated as a percent of their baseline $\triangle F^{\prime} V_{1.0}$ per $\mathrm{mg} / \mathrm{m}^{3}$ (the mean of two baseline observations) and is presented in Fig. 1 and Appendix 1. Paired $t$ tests were completed using both control trials for subsequent steaming trials to test for differences in unadjusted $\triangle F V_{1.0}$ among surviving panel members (Appendix 1). Similarly, $t$ tests for dust level differences between control and steaming trials by work area were conducted using a minimum of six paired dust levels for each test (Fig. 2).

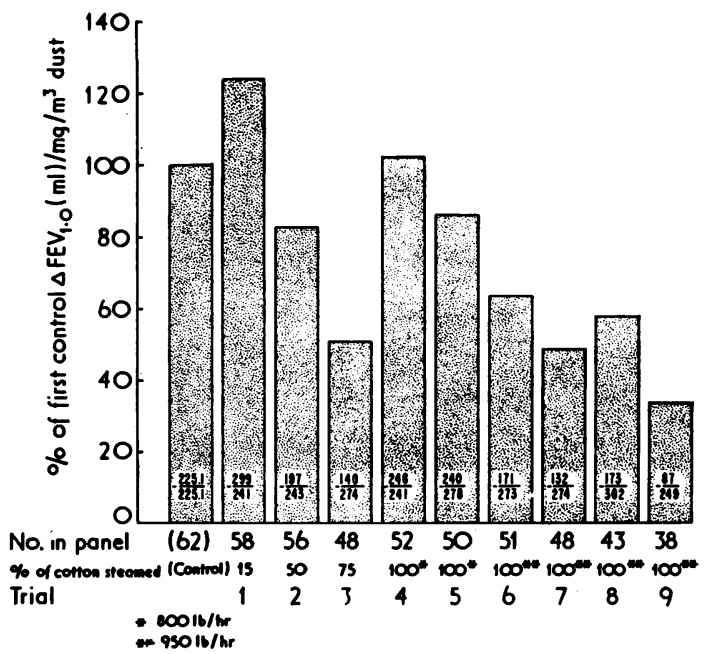

FIG. 1. Percent of control change in $\mathrm{FEV}_{1.0}$ with six hours of cotton dust exposure among panel members during steaming intervention trials, North Carolina, 1972-73. 


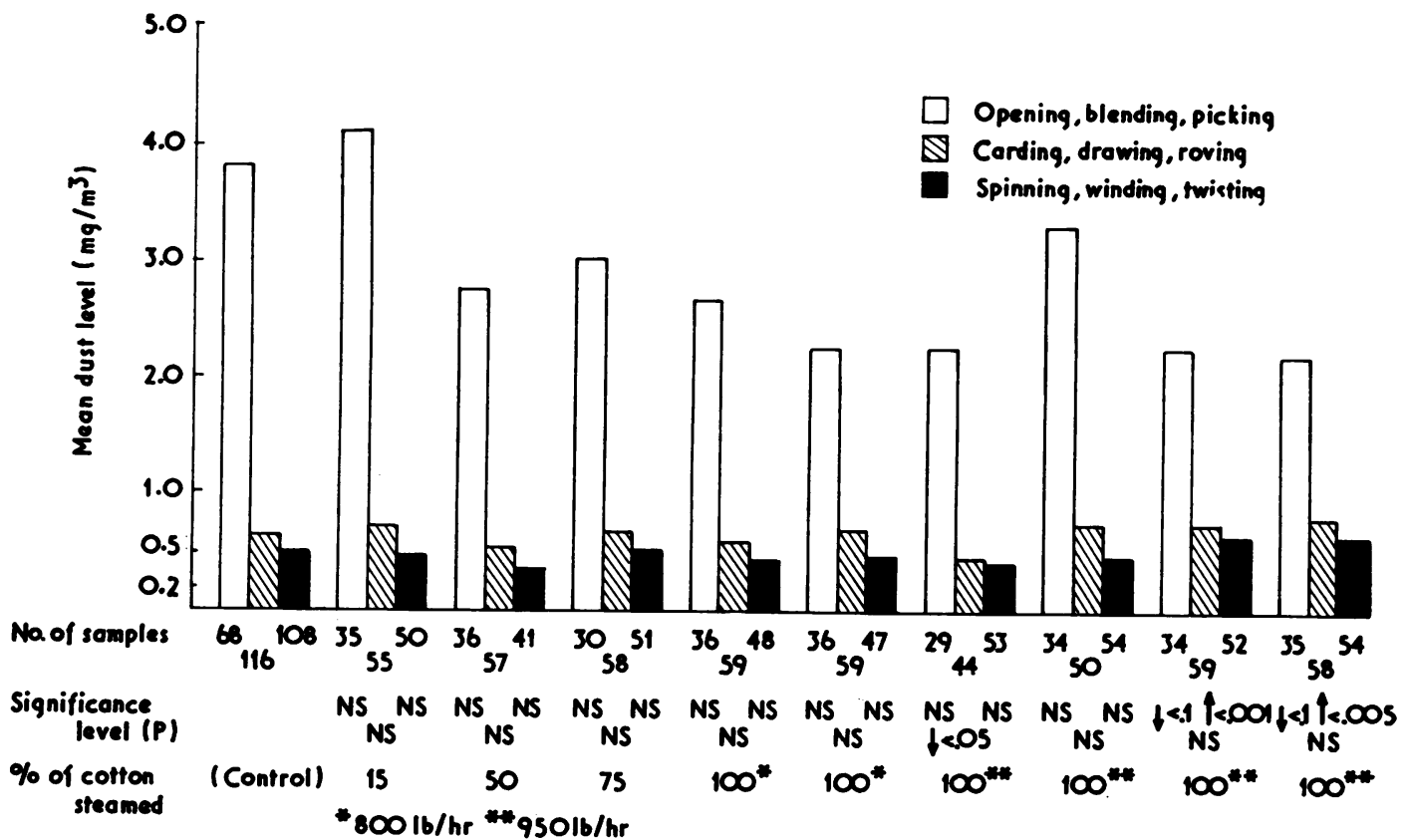

FIG. 2. Mean vertical elutriator dust levels by work area during steaming intervention trials, North Carolina, 1972-73.

Results

Of those eligible to participate in the plantwide survey preceding steaming intervention (1972), $97.7 \%$ were administered the questionnaire and $83.5 \%$ participated in pulmonary function testing (Table 2). Ten months later, at the end of the intervention study (1973), six workers had transferred to non-manufacturing jobs, 78 had terminated employment or were absent, and one declined to participate in the survey. Two hundred and eight-seven or $75.3 \%$ of those originally eligible participated in the second plantwide survey. At the time of the 1972 survey, $10 \%$ of the study population was employed in opening and picking areas, $18 \%$ in carding, $33 \%$ in spinning, and $39 \%$ in winding and twisting. By the time of the 1973 survey $44 \%$ of those in opening and picking areas had left the mill or transferred to other areas, $20 \%$ had left the carding area, while $21 \%$ had left spinning and $19 \%$ the winding/twisting area.

TABLE 2

Steaming Intervention Survey Participation by Work Area, 1972-1973

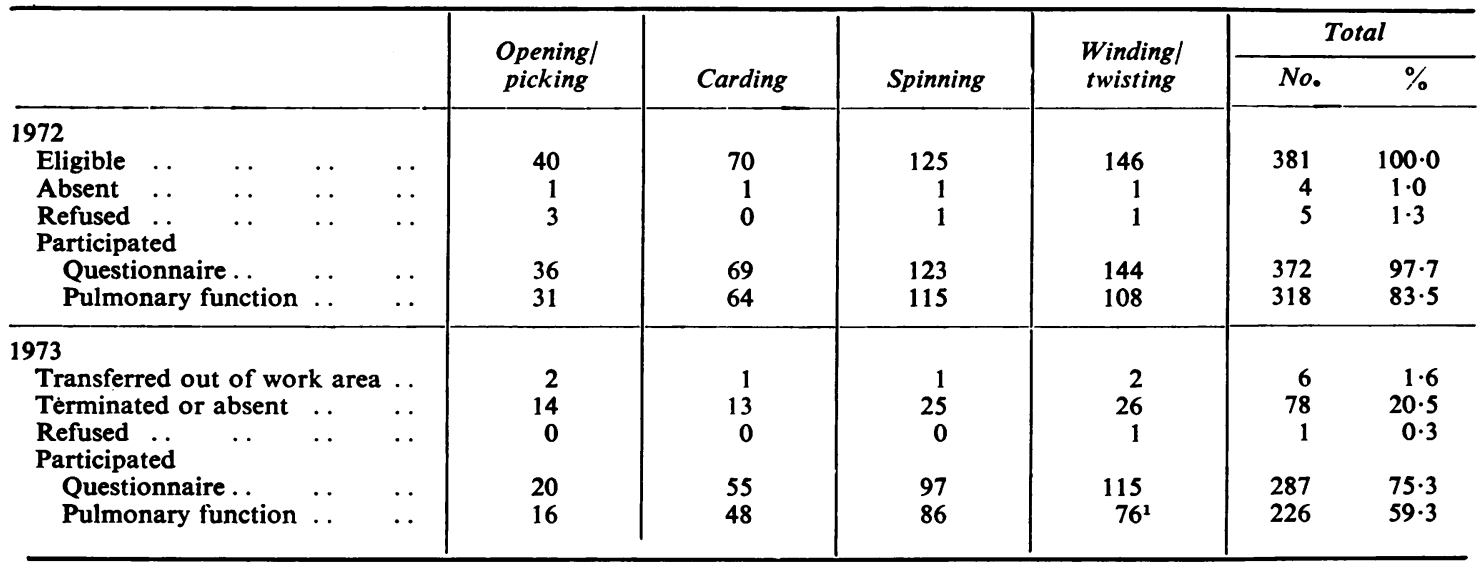

1 Excluding those without a weekend break 
Six transferred within the study population, all to areas of similar or lower dust exposure. All those employed in opening, picking, and carding areas were men, while the majority in spinning, winding, and twisting were women (Table 3). Forty percent of the study population was black, including a high of $64 \%$ in opening and picking, to a low of $28 \%$ in spinning. The greater frequency of cigarette smoking in opening/picking and carding areas is a reflection of male smoking habits. Despite the finding that over $50 \%$ of those working in winding/twisting areas were women, the percentage of current smokers was nearly as great as that in the all-male opening/picking areas. It is further observed that there were over five times the number of former smokers in the opening/ picking area as in winding/twisting with a decreasing frequency of former smokers from opening/picking to winding/twisting.

The composition of the test panel differed from the entire study population in several important respects (Table 4). Nearly the entire test panel was male and over $70 \%$ were employed in the opening/ picking and carding areas. Smoking histories revealed only a slightly greater smoking frequency, but many more had respiratory symptoms. Despite the high prevalence of respiratory symptoms, the mean $\mathrm{FEV}_{1.0}$ for the group was within the normal range, $83 \%$ of predicted for height, age, and sex, although several individuals within the group had abnormally low values.

Changes in FEV 1.0 among panel members over the nine trials, relative to the survivors' baseline $\triangle F V_{1.0}$ levels, are expressed as a percent of their baseline changes and are summarized in Fig. 1 and Appendix 1. These data suggest a significant improvement in the panel $\triangle F^{\prime} V_{1.0}$ with $50-75 \%$ of the cotton steamed, but a loss of this improvement in $\triangle F E V_{1.0}$ when $100 \%$ of cotton was being steamed but at low steam volume (trials 4 and 5 ). With increased steam volume, consistently significant improvements in the test panel $\triangle F E V_{1.0}$, averaging
$50 \%$ of control levels, were observed over the last four trials.

Dust samples, which were taken in quantity to assure stable mean and median levels, are summarized in Fig. 2 and Appendix 2 and reveal a somewhat different pattern. After introduction of $100 \%$ steamed cotton, moderate but statistically insignificant reductions in dust levels were observed in the combined areas of opening, blending, and picking. In contrast, significant increases in dust levels in the combined areas of spinning, winding, and twisting and a mill-wide increase in median dust level of $30 \%$

\section{TABLE 4}

Composition of Test Panel by Demographic Characteristics, Work Area, SMOKIng History, RESPIRATORY SYMPTOMS, AND FEV 1.0

\begin{tabular}{|c|c|c|c|c|c|}
\hline Number & . & . & . & . & 62 \\
\hline $\begin{array}{l}\text { Male (\%) } \\
\text { Mean age } \\
\text { Race, } \% \text { black }\end{array}$ & $\begin{array}{l}\cdots \\
\cdots \\
\cdots\end{array}$ & $\begin{array}{l}\cdots \\
\cdots \\
\cdots\end{array}$ & $\begin{array}{l}\cdots \\
\cdots \\
\cdots\end{array}$ & $\begin{array}{l}\cdots \\
\cdots \\
\cdots\end{array}$ & $\begin{array}{l}90 \cdot 3 \\
38 \cdot 3 \\
35 \cdot 5\end{array}$ \\
\hline $\begin{array}{l}\text { Work area } \\
\text { Opening/picking } \\
\text { Carding (\%) } \\
\text { Spinning (\%) } \\
\text { Winding/twisting }\end{array}$ & $\begin{array}{l}(\%) \\
\cdots \\
(\%)\end{array}$ & $\begin{array}{l}\cdots \\
\cdots \\
\cdots\end{array}$ & $\begin{array}{l}\cdots \\
\cdots \\
\cdots \\
\cdots\end{array}$ & $\begin{array}{l}\cdots \\
\cdots \\
\cdots \\
\cdots\end{array}$ & $\begin{array}{l}27 \cdot 5 \\
43 \cdot 5 \\
11 \cdot 3 \\
17 \cdot 7\end{array}$ \\
\hline $\begin{array}{l}\text { Smoking history } \\
\text { Current smokers } \\
\text { Mean no. cigs/ } \\
\text { Ever smoked ( \%) } \\
\text { Mean no. pack }\end{array}$ & $\begin{array}{l}(\%) \\
\text { day } \\
\cdots \\
\text { years }\end{array}$ & $\begin{array}{l}\cdots \\
\cdots \\
\cdots \\
\cdots\end{array}$ & $\begin{array}{l}\cdots \\
\cdots \\
\cdots\end{array}$ & $\begin{array}{l}\ldots \\
\cdots \\
\cdots \\
\cdots\end{array}$ & $\begin{array}{l}59 \cdot 7 \\
16 \cdot 1 \\
82 \cdot 3 \\
13 \cdot 9\end{array}$ \\
\hline $\begin{array}{c}\text { Respiratory sympto } \\
\text { Byssinosis } 1 / 2+ \\
\text { Bronchitis } 1+2 \\
\text { Dyspnoea } 3+(\%\end{array}$ & $\begin{array}{l}\mathrm{ms} \\
1+2( \\
+3(\%\end{array}$ & 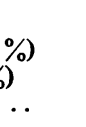 & $\begin{array}{l}\cdots \\
\cdots \\
\cdots\end{array}$ & $\begin{array}{l}\cdots \\
\cdots \\
\cdots\end{array}$ & $\begin{array}{l}61 \cdot 3 \\
27 \cdot 4 \\
11 \cdot 3\end{array}$ \\
\hline 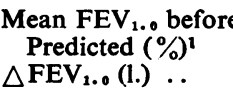 & $\begin{array}{l}\text { expos } \\
\ldots \\
\ldots\end{array}$ & $\begin{array}{l}\text { ure (1.) } \\
\ldots \\
\ldots\end{array}$ & $\begin{array}{l}. . \\
\cdots \\
.\end{array}$ & $\begin{array}{l}\cdots \\
\cdots \\
\cdots\end{array}$ & $\begin{array}{c}3 \cdot 157 \\
83 \cdot 1 \\
-0 \cdot 225\end{array}$ \\
\hline
\end{tabular}

${ }^{1}$ Boren, Kory, and Syner (1966) 
TABLE 5

Respiratory Symptom Prevalence and FEV 1.0 among Surviving Panel Members before (1972) AND AFTER (1973) STEAMING INTERVENTION

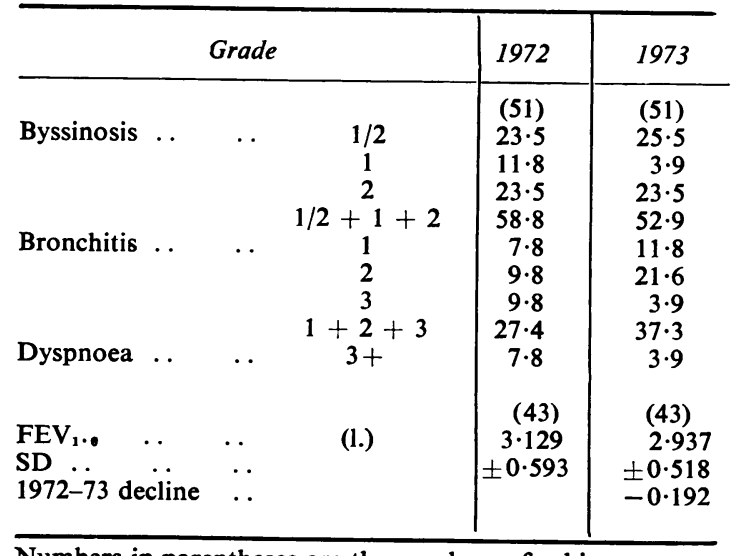

Numbers in parentheses are the numbers of subjects were observed in the last two trials, at which time steaming was best controlled and most efficiently applied. No significant change in carding area dust level over the nine trials was observed except for a reduction during trial 6 , in which dust levels were generally reduced.

Tables 5 and 6 review the prevalence of respiratory symptoms during the 1972 and 1973 surveys. The test panel was found to have a slight decrease in byssinosis prevalence but an increase in bronchitis prevalence. Only those working the opening and picking area showed an increase in symptom prevalence. Minimal to moderate increases in byssinosis symptoms occurred in carding, spinning, and winding/twisting areas while greater increases in bronchitis prevalence were observed in these areas. No difference was observed in dyspnoea prevalence or in advanced grades of any symptom in any work area when the two surveys were compared.

When pulmonary function data collected during the two mill-wide surveys were considered (Tables 7

TABLE 6

Byssinosis and Bronchitis Prevalence among Survivors by Grade and Work Area before (1972) AND AFTER (1973) STEAMING INTERVENTION

\begin{tabular}{|c|c|c|c|c|c|c|}
\hline \multirow{2}{*}{ Work area } & \multicolumn{3}{|c|}{ Byssinosis prevalence $(\%)$} & \multicolumn{3}{|c|}{ Bronchitis prevalence $(\%)$} \\
\hline & Grade & 1972 & 1973 & Grade & 1972 & 1973 \\
\hline \multirow[t]{3}{*}{ Opening/picking } & & (19) & (19) & & (19) & (19) \\
\hline & $\begin{array}{c}1 / 2 \\
1 \\
2\end{array}$ & $\begin{array}{l}15 \cdot 8 \\
10 \cdot 5 \\
26 \cdot 3\end{array}$ & $\begin{array}{l}15 \cdot 8 \\
15 \cdot 8 \\
15 \cdot 8\end{array}$ & $\begin{array}{l}1 \\
2 \\
3\end{array}$ & $\begin{array}{l}10 \cdot 5 \\
10 \cdot 5 \\
10 \cdot 5\end{array}$ & $\begin{array}{r}10 \cdot 5 \\
15 \cdot 8 \\
5 \cdot 3\end{array}$ \\
\hline & $1 / 2+1+2$ & $52 \cdot 6$ & $47 \cdot 4$ & $1+2+3$ & $31 \cdot 5$ & $31 \cdot 6$ \\
\hline \multirow[t]{3}{*}{ Carding } & & (53) & (53) & & (53) & (53) \\
\hline & $\begin{array}{c}1 / 2 \\
1 \\
2\end{array}$ & $\begin{array}{r}17 \cdot 0 \\
7 \cdot 5 \\
9 \cdot 4\end{array}$ & $\begin{array}{r}20 \cdot 8 \\
5 \cdot 7 \\
11 \cdot 3\end{array}$ & $\begin{array}{l}1 \\
2 \\
3\end{array}$ & $\begin{array}{l}3 \cdot 8 \\
7 \cdot 5 \\
3 \cdot 8\end{array}$ & $\begin{array}{r}5 \cdot 7 \\
17 \cdot 0 \\
3 \cdot 8\end{array}$ \\
\hline & $1 / 2+1+2$ & $33 \cdot 9$ & $37 \cdot 8$ & $1+2+3$ & $15 \cdot 1$ & $26 \cdot 5$ \\
\hline \multirow[t]{3}{*}{ Spinning } & & (90) & (90) & & (90) & (90) \\
\hline & $\begin{array}{c}1 / 2 \\
1 \\
2\end{array}$ & $\begin{array}{l}7 \cdot 8 \\
1 \cdot 1 \\
2 \cdot 2 \\
\end{array}$ & $\begin{array}{r}14 \cdot 4 \\
3 \cdot 3 \\
0 \cdot 0 \\
\end{array}$ & $\begin{array}{l}1 \\
2 \\
3\end{array}$ & $\begin{array}{l}3 \cdot 3 \\
1 \cdot 1 \\
2 \cdot 2 \\
\end{array}$ & $\begin{array}{l}8 \cdot 9 \\
4 \cdot 4 \\
2 \cdot 2 \\
\end{array}$ \\
\hline & $1 / 2+1+2$ & $11 \cdot 1$ & $17 \cdot 7$ & $1+2+3$ & $6 \cdot 6$ & $15 \cdot 5$ \\
\hline \multirow[t]{3}{*}{ Winding/twisting } & & $(105)$ & $(105)$ & & (105) & $(105)$ \\
\hline & $\begin{array}{l}1 / 2 \\
1 \\
2\end{array}$ & $\begin{array}{l}4 \cdot 8 \\
1 \cdot 0 \\
3 \cdot 8\end{array}$ & $\begin{array}{l}5 \cdot 7 \\
1.9 \\
3 \cdot 8\end{array}$ & $\begin{array}{l}1 \\
2 \\
3\end{array}$ & $\begin{array}{l}1.9 \\
2.9 \\
1.9\end{array}$ & $\begin{array}{l}6 \cdot 7 \\
5 \cdot 7 \\
1.9\end{array}$ \\
\hline & $1 / 2+1+2$ & $9 \cdot 6$ & $11 \cdot 4$ & $1+2+3$ & $6 \cdot 7$ & $14 \cdot 3$ \\
\hline
\end{tabular}


TABLE 7

Mean Change in FeV 1.0 and Adjusted Mean Change in FEV 1.0 by Work Area before (1972) AND AFTER (1973) STEAMING INTERVENTION

\begin{tabular}{|c|c|c|c|c|c|c|c|c|c|}
\hline \multirow{2}{*}{ Work area } & & & \multicolumn{3}{|c|}{$\begin{array}{c}\text { Before steaming } \\
(1972)\end{array}$} & \multicolumn{3}{|c|}{$\begin{array}{l}\text { After steaming } \\
\quad(1973)\end{array}$} & \multirow[t]{2}{*}{$\mathbf{P}$} \\
\hline & & & $\mathbf{n}$ & $\Delta \mathrm{FEV}_{1.0}(1)$. & $\pm \mathrm{SD}$ (1.) & $\mathbf{n}$ & $\triangle \mathrm{FEV}_{1.0}(1)$. & \pm SD (1.) & \\
\hline $\begin{array}{ll}\begin{array}{c}\text { Opening/picking } \\
\text { All surveyed }\end{array} & \ldots \\
\text { Adjusted to } & 1 \mathrm{mg} / \mathrm{m}^{3} \\
\begin{array}{c}\text { Survivors } \\
\text { Adjusted to }\end{array} & \because \mathrm{mg} / \mathrm{m}^{3}\end{array}$ & $\begin{array}{l}\cdots \\
\cdots \\
\cdots\end{array}$ & $\begin{array}{l}\cdots \\
\cdots \\
\cdots \\
\cdots\end{array}$ & $\begin{array}{l}31 \\
13\end{array}$ & $\begin{array}{l}-0.195 \\
-0.047 \\
-0.278 \\
-0.069\end{array}$ & $\begin{array}{l} \pm 0.308 \\
\pm 0.074 \\
\pm 0.386 \\
\pm 0.095\end{array}$ & $\begin{array}{l}15 \\
13\end{array}$ & $\begin{array}{l}+0.054 \\
+0.021 \\
+0.001 \\
-0.002\end{array}$ & $\begin{array}{l} \pm 0.285 \\
\pm 0.117 \\
\pm 0.264 \\
\pm 0.104\end{array}$ & $<0.05$ \\
\hline $\begin{array}{l}\text { Carding } \\
\begin{array}{l}\text { All surveyed } \\
\text { Adjusted to }\end{array} \\
\begin{array}{l}\text { Survivors } \\
\text { Adjusted to }\end{array}\end{array}$ & $\begin{array}{l}\ldots \\
\ldots \\
\ldots \\
\cdots\end{array}$ & $\begin{array}{l}\cdots \\
\cdots \\
\cdots \\
\cdots\end{array}$ & $\begin{array}{l}63 \\
45\end{array}$ & $\begin{array}{l}-0.115 \\
-0.192 \\
-0.127 \\
-0.206\end{array}$ & $\begin{array}{l} \pm 0.212 \\
\pm 0.339 \\
\pm 0.219 \\
\pm 0.368\end{array}$ & $\begin{array}{l}48 \\
45\end{array}$ & $\begin{array}{l}-0.075 \\
-0.079 \\
-0.072 \\
-0.077\end{array}$ & $\begin{array}{l} \pm 0.211 \\
\pm 0.256 \\
\pm 0.212 \\
\pm 0.260\end{array}$ & NS \\
\hline $\begin{array}{l}\text { Spinning } \\
\begin{array}{l}\text { All surveyed } \\
\text { Adjusted to }\end{array} \\
\begin{array}{l}\text { Survivors } \\
\text { Adjusted to }\end{array}\end{array}$ & $\begin{array}{l}\ldots \\
\cdots \\
\cdots \\
\cdots\end{array}$ & $\begin{array}{l}\cdots \\
\cdots \\
\cdots \\
\cdots\end{array}$ & $\begin{array}{r}106 \\
70\end{array}$ & $\begin{array}{l}-0.044 \\
-0.121 \\
-0.044 \\
-0.125\end{array}$ & $\begin{array}{l} \pm 0.142 \\
\pm 0.395 \\
\pm 0.147 \\
\pm 0.407\end{array}$ & $\begin{array}{l}84 \\
70\end{array}$ & $\begin{array}{l}-0.054 \\
-0.085 \\
-0.062 \\
-0.097\end{array}$ & $\begin{array}{l} \pm 0 \cdot 194 \\
\pm 0.304 \\
\pm 0 \cdot 205 \\
\pm 0.320\end{array}$ & NS \\
\hline 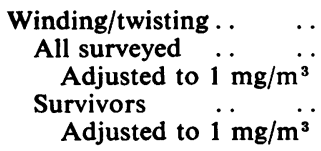 & $\begin{array}{l}\cdots \\
\cdots \\
\cdots \\
\cdots \\
\cdots\end{array}$ & $\begin{array}{l}\cdots \\
\cdots \\
\cdots \\
\cdots\end{array}$ & $\begin{array}{l}108 \\
65^{1}\end{array}$ & $\begin{array}{l}-0.074 \\
-0.140 \\
-0.071 \\
-0.132\end{array}$ & $\begin{array}{l} \pm 0.147 \\
\pm 0.279 \\
\pm 0.153 \\
\pm 0.284\end{array}$ & $\begin{array}{l}76^{1} \\
65^{1}\end{array}$ & $\begin{array}{l}-0.027 \\
-0.044 \\
-0.028 \\
-0.037\end{array}$ & $\begin{array}{l} \pm 0.163 \\
\pm 0.267 \\
\pm 0.162 \\
\pm 0.266\end{array}$ & NS \\
\hline
\end{tabular}

${ }^{1}$ Excluding those without a weekend break

TABLE 8

Mean FEV 1.0 And Annual Decline in FEV 1.0 by Work Area before (1972) and after (1973) STEAMING INTERVENTION

\begin{tabular}{|c|c|c|c|c|c|c|c|c|c|}
\hline \multirow{2}{*}{ Work area } & & & & \multicolumn{3}{|c|}{$\begin{array}{c}\text { Before steaming } \\
(1972)\end{array}$} & \multicolumn{3}{|c|}{$\begin{array}{c}\text { After steaming } \\
(1973)\end{array}$} \\
\hline & & & & $\mathrm{n}$ & $\mathrm{FEV}_{1 \cdot 0}$ (1.) & SD (1.) & $\mathbf{n}$ & $\mathrm{FEV}_{1.0}(1)$. & SD (1.) \\
\hline $\begin{array}{l}\text { Opening/picking } \\
\text { All surveyed } \\
\text { Survivors } \\
1972-73 \text { decline }\end{array}$ & $\begin{array}{l}\ldots \\
\cdots \\
\cdots\end{array}$ & $\begin{array}{l}\cdots \\
\cdots \\
\cdots\end{array}$ & $\begin{array}{l}\cdots \\
\cdots \\
\cdots\end{array}$ & $\begin{array}{l}31 \\
14\end{array}$ & $\begin{array}{l}3 \cdot 159 \\
3 \cdot 112\end{array}$ & $\begin{array}{l} \pm 0.654 \\
\pm 0.633\end{array}$ & $\begin{array}{l}16 \\
14 \\
14\end{array}$ & $\begin{array}{r}2.937 \\
2 \cdot 820 \\
-0.292\end{array}$ & $\begin{array}{l} \pm \mathbf{0 . 5 8 2} \\
\pm \mathbf{0 . 5 0 5}\end{array}$ \\
\hline $\begin{array}{l}\text { Carding } \\
\text { All surveyed } \\
\text { Survivors } \\
1972-73 \text { decline }\end{array}$ & $\begin{array}{l}\cdots \\
\cdots \\
\cdots\end{array}$ & $\begin{array}{l}\cdots \\
\cdots \\
\cdots\end{array}$ & $\begin{array}{l}\cdots \\
\cdots \\
\cdots\end{array}$ & $\begin{array}{l}64 \\
46\end{array}$ & $\begin{array}{l}3 \cdot 400 \\
3 \cdot 335\end{array}$ & $\begin{array}{l} \pm 0.673 \\
\pm 0.586\end{array}$ & $\begin{array}{l}48 \\
46 \\
46\end{array}$ & $\begin{array}{r}3 \cdot 168 \\
3 \cdot 190 \\
-0 \cdot 145\end{array}$ & $\begin{array}{l} \pm 0.554 \\
\pm 0.556\end{array}$ \\
\hline $\begin{array}{l}\text { Spinning } \\
\text { All surveyed } \\
\text { Survivors } \\
1972-73 \text { decline }\end{array}$ & $\begin{array}{l}\cdots \\
\cdots \\
\cdots\end{array}$ & $\begin{array}{l}\cdots \\
\cdots \\
\cdots\end{array}$ & $\begin{array}{l}\cdots \\
\cdots \\
\cdots\end{array}$ & $\begin{array}{r}115 \\
74\end{array}$ & $\begin{array}{l}3.023 \\
3.015\end{array}$ & $\begin{array}{l} \pm 0.774 \\
\pm 0.735\end{array}$ & $\begin{array}{l}86 \\
74 \\
74\end{array}$ & $\begin{array}{r}2.879 \\
2.927 \\
-0.088\end{array}$ & $\begin{array}{l} \pm 0.667 \\
\pm 0.672\end{array}$ \\
\hline $\begin{array}{l}\text { Winding/twisting } \\
\text { All surveyed } \\
\text { Survivors } \\
\text { 1972-73 decline }\end{array}$ & $\begin{array}{l}\ldots \\
\cdots \\
\ldots\end{array}$ & $\begin{array}{l}\ldots \\
\cdots \\
\ldots\end{array}$ & $\begin{array}{l}\ldots \\
\cdots \\
\cdots\end{array}$ & $\begin{array}{c}108 \\
65^{1}\end{array}$ & $\begin{array}{l}2 \cdot 825 \\
2 \cdot 772\end{array}$ & $\begin{array}{l} \pm 0.699 \\
\pm 0.755\end{array}$ & $\begin{array}{l}76^{1} \\
65^{1} \\
65^{1}\end{array}$ & $\begin{array}{r}2.646 \\
2.706 \\
-0.067\end{array}$ & $\begin{array}{l} \pm 0.697 \\
\pm 0.714\end{array}$ \\
\hline
\end{tabular}

${ }^{1}$ Excluding those without a weekend break 
and 8), somewhat different results were obtained. In the opening/picking area there was a pronounced improvement in $\triangle F^{\prime} V_{1.0}$ in 1973 (Table 7), but this largely disappeared when $\triangle F E_{1.0}$ was adjusted to account for the reduction in dust level. In the other three work areas, there was consistent evidence of decreased biological activity in carding and winding/twisting areas after adjustment for dust level. However, pre-exposure FEV $_{1.0}$ was consistently reduced in 1973 relative to the 1972 values (Tables 5 and 8). A 10-month decline of 0.2921 . was observed in the 14 survivors of the opening/picking area while the 43 surviving panel members had a decline of $0 \cdot 1921$. Progressively smaller declines in pre-exposed $F E V_{1.0}$ were found in areas subsequent to preparation.

\section{Discussion}

The purpose of this intervention study was to test, under manufacturing conditions, a method of steaming cotton which tested in an experimental exposure chamber had reduced lint-free dust levels more than $50 \%$. The biological activity of the remaining dust, as measured by $\triangle F E V_{1.0}$, was similarly reduced (Merchant et al., 1973a). Although improved machine exhaust and ventilation would still be required to achieve safe working conditions in preparation and carding areas, it was thought that this method might improve environmental conditions in subsequent work areas sufficiently for additional environmental control not to be necessary.

As in previous experimental trials, a test panel was selected primarily on criteria of current symptoms and exposure. This resulted in a panel of sensitive subjects that was heavily weighted toward those employed in earlier processes. As a result conclusions drawn during individual trials as to the effect of steaming on biological activity of cotton dust were based largely on its effect on $\triangle F E V_{1.0}$ in sensitive subjects employed in the areas of opening/picking and carding. Using $\triangle F^{\prime} V_{1.0}$ as the primary indicator of biological activity, it appeared that a significant reduction in biological activity was achieved when the mill was processing $75 \%$ steamed cotton. When steam volume was reduced and steam was applied inefficiently, $\triangle F E V_{1.0}$ returned to control levels, then improved significantly with higher steam volumes and more efficient application. Significant improvements in the test panel $\triangle F E_{1.0}$ were confirmed in the 1973 plantwide survey and are consistent with results obtained in previous exposure chamber studies but were not accompanied by a decreased prevalence of symptoms.

Several points should be considered in the interpretation of symptom prevalence. Since it is unlikely that these changes occurred by chance or are attributable to a loss in responsiveness in the population, these possibilities can be set aside. However, it is possible that the change in the work week following the first steaming trial, from a fiveday week with a 64-hour weekend to a six-day week with a 40-hour weekend, affected results. Tachyphylaxis has been described with cotton dust exposure (McKerrow, McDermott, Gilson, and Schilling, 1958; Bouhuys, Lindell, and Lundin, 1960) and could systematically reduce decrements in $F V_{1.0}$ independent of any steaming effect. This possibility was examined in a panel of 12 workers during previous experimental trials (Merchant et al., 1973a); the short weekend was not found systematically to reduce pre-exposure $\mathrm{FEV}_{1.0}$ levels nor to produce a consistent reduction in $\triangle F E V_{1.0}$. Supporting these findings is the observation that the $\triangle F E V_{1.0}$ of the test panel, in the study reported herein, approached control levels (established with a 64-hour weekend) following 40-hour weekends when cotton was being ineffectively steamed (trials 4 and 5) and then improved significantly with improved steaming in later trials. Although the possibility that tachyphylaxis may have contributed to a decreased $\triangle F E V_{1.0}$ in later trials cannot be discounted, available information suggests that it was not of major importance. Another possibility is a systematic difference in questionnaire administration or response. Care was taken that the identical questionnaire and the same interviewer were employed during both studies. The study population was necessarily aware of the purpose of the study, was co-operative, and had no known reason for falsely responding to questions. The uniform increase in symptom prevalence (Table 6) observed in all areas except opening/picking may well represent the cumulative effects of 10 additional months of exposure together with increased dust levels in those work areas.

That symptoms increased while $\triangle F V_{1.0}$ decreased significantly raises a question relevant not only to interpretation of this study but also to the search for aetiological agents. Since McKerrow et al. (1958) reported consistent decreases in expiratory flow among textile workers, particularly among those with byssinosis, a number of studies have measured smooth muscle contraction as the indicator of biological response (Bouhuys, Lindell, and Lundin, 1960; Davenport and Paton, 1962; Bouhuys and Nicholls, 1966). Furthermore there is evidence that vegetable dusts liberate histamine (Bouhuys and Lindell, 1961; Nicholls, Nicholls, and Bouhuys, 1966; Hitchcock, Piscitelli, and Bouhuys, 1973). Consequently, non-specific histamine release has been used as an important indicator in byssinosis research and measurement of expiratory flow has been widely used as an objective indicator of byssinosis 'risk' (Berry et al., 1973).

It has not been established, however, whether the 
flow rate response and the typical chest discomfort or tightness share a common aetiology and mechanism or whether they are distinct yet strongly associated phenomena. Bouhuys and Nicholls (1966) observed that although the physiological changes in airway mechanics were the same when their subjects inhaled histamine and cotton bract extract, their symptoms experienced with histamine-a 'choking sensation'-differed from those produced by bract extract which in addition produced a 'painful feeling of constriction' more typical of byssinosis. Epidemiological studies suggest that many subjects experience significant flow reductions in the absence of symptoms of chest tightness (Molyneux and Tombleson, 1970; Imbus and Suh, 1973). Similarly, we observed some disparity between the flow response and chest tightness response in previous steaming trials (Merchant et al., 1973a). In those trials with raw cotton dust a strong linear association $(r=0.97)$ between $\triangle F E V_{1.0}$ and symptom prevalence was observed, while the same correlation for steamed cotton dust was $\mathbf{0} \cdot 34$. Also in that study, the regression of symptom prevalence on respirable dust for raw and steamed cotton trials suggested that there were fewer symptoms at all levels of steamed dust exposure; however, the slope of the two regressions did not differ. By contrast, the slopes for $\triangle F E V_{1.0}$ on dust during raw cotton and steamed cotton trials did differ.

Consequently, serious consideration must be given to the hypothesis of two or multiple biologically active agents in cotton dust, as suggested by Davenport and Paton (1962). A large number of steam volatile agents have been found in cotton dust (Hedin, Thompson, and Gueldner, 1973), but their biological activity has not been tested. Klein, Rapoport, and Elliott (1971) have described a volatile low molecular weight piperidine isolated from hemp, and Hitchcock et al. (1973) have described a steam volatile material from cotton bracts with the characteristics of methyl piperonylate which was found to release histamine from chopped human lung. Partial elimination of biologically active, steam volatile agent(s) may explain the reduction in $\triangle F E V_{1.0}$ while other agents, less responsive to steam, may remain in the dust and contribute to the symptomatic response and perhaps the chronic effect. Two such agents found in cotton dust may be endotoxin (Cavagna, Foa, and Vigliani, 1969) and condensed tannins (Taylor, Massoud, and Lucas, 1971; Kilburn, Lynn, Tres, and McKenzie, 1973), extracts of which have been found to cause 'acute bronchitis' in animal models. This hypothesis is consistent with the results of this intervention study; further experimental studies may explain the apparent differences between the effect of steam upon flow rates and symptoms.

Interpretation of the effect of steaming on dust levels during these trials is also difficult. At two points, trial 2 and trial 9, it appeared that consistent reductions in dust levels were being achieved. Subsequent trials, during which steaming was thought to be most efficient and at which time the most significant reductions in $\triangle F E V_{1.0}$ were observed, resulted in a consistent decrease in dust level in preparation areas but increased levels in subsequent processes. Although the blending area is not a good area in which to judge effects, since some unsteamed cotton is handled in this area, opening and picking areas handled only steamed cotton. In these two areas, consistent reductions in median dust level of 25 to $40 \%$ were observed from trial 4 to trial 9. By contrast, dust levels generally rose in all processes after picking, and significantly by paired $t$ test $(\mathrm{P}<0.005)$ in spinning and winding/twisting areas in the last two trials when steaming was best controlled. This post-preparation increase in dust level occurred in all processes, with the greatest percent increase in roving and spinning areas.

Several points must be considered in interpreting these findings. A change in cotton crop was instituted toward the end of the trials. Although the cotton grade and count was the same, differences in trash content occur from season to season. Had this been a major factor, however, one would expect to see increased dust levels in all work areas. This was not observed. Another possibility is a change in exhaust or ventilation systems that could differentially provide better conditions in opening/picking but poorer conditions in other areas. Although improved ventilation was provided in the immediate area of the steamers (blending), no other change in exhaust or ventilation systems was made over the 10 months of the study. Another possible explanation is a change in yarn processing equipment or processing efficiency or speed in some work areas. No change was made in processing equipment or speed, but some increase in processing efficiency may have occurred as the result of steaming. This may have allowed more frames to run a greater percentage of time which could have increased dust levels in areas such as spinning. Although this is unlikely it cannot be ruled out and may have contributed to increased dust levels in some areas.

Because of the many variables that can influence dust levels in a cotton spinning mill, it is difficult to separate steaming effect from variability imposed by other factors. However, based on large numbers of dust samples and consistent trends, the results are consistent with the following argument. During previous experimental trials significant reductions in respirable dust level and $\triangle F E V_{1.0}$ were found when bound bales of cotton were steamed under pressure in an autoclave (Merchant et al., 1973a). Since the bale was bound, it was thought that although volatile materials could be removed, particulates 
would be largely retained. Since dust levels were clearly reduced upon processing this cotton in the exposure chamber, it was postulated that steam applied under pressure could be binding fine dust particles to the cotton fibre. However, when steaming was done without pressure and the exhaust from the steamer condensed on the roof of the mill, several square yards of roof top were covered with brown powder which suggested that the high-capacity steaming process was removing some dust. It is consistent with the results of the trials reported herein that some dust may be removed, that some biological activity of the dust was removed, but that binding of dust to the fibre may also have occurred. This could explain the reduction in dust level and the $\triangle F E V_{1.0}$ found in the preparation area, which is analogous to the single process used in previous exposure chamber trials. With further processing, during which the fibre is carded, drawn, and spun, some of the fine dust adhered to the fibre by steam may be released, thereby increasing the dust levels in these work areas which more than offset any decrease in $\triangle F E V_{1.0}$ and appeared to be associated with an increase in prevalence of byssinosis and bronchitis symptoms.

Regardless of the mechanism by which environmental conditions were altered during this study, it is clear that steaming cotton under these conditions did not provide a uniform reduction in dust level nor a satisfactory reduction in all indices of 'biological activity' of cotton dust. In fact, if steaming resulted in binding of fine dust to the cotton fibre, which we suspect, conditions in later processing areas may have been made worse by the use of steam. Since $90 \%$ of the work force is employed in areas subsequent to preparation, it must be concluded that steaming as performed and tested in this study provided no overall improvement in environmental conditions. Supporting this conclusion is the large 10-month decrement in pre-exposure $\mathrm{FEV}_{1.0}$ among panel members and those working in the opening/ picking area which is eight to 10 times that attributable to aging (Kory, Callahan, Boren, and Syner, 1961; Ferris, Anderson, and Zickmantel, 1965), five times as great as the aging effect in carding, and two to three times as great in spinning and winding/twisting areas. Also consistent with the large annual decrement among those in the opening/picking area were indirect indicators of 'risk', the $44 \%$ attrition in number of workers, and the excess number of former smokers in this area.

Questions were raised throughout the study as to the effectiveness of steam application during day-today manufacturing relative to that achieved when the designers of the equipment were supervising steaming. Results obtained in the preparation area during efficient steaming with later steaming trials suggest that previous exposure chamber results were fairly well reproduced during these trials. However, when steaming was being conducted with maximum efficiency and control (trials 8 and 9), significant increases in dust levels were found in later processes. This suggests that even more efficient steaming by this particular process is not likely greatly to alter these findings. If preprocessing of cotton is to be pursued as a means of preventing respiratory disease in the cotton textile industry, attention should be focused on removal of fine dust particles. Because Schilling's (1962) observation that preventive measures have largely failed remains valid today, whether adequate dust control will be achieved with exhaust ventilation equipment remains an important question and a challenge to the cotton textile industry.

This study was supported by a training grant from the National Institute of Environmental Health Science, grant 2T01ES00124, and by a grant from the National Institute of Occupational Safety and Health, grant 5R010H00302.

We wish to thank Bonita Searle and Cathy Ambrose for preparation of the manuscript and the employees and management of Burlington Industries Smithfield Spinning Plant for their co-operation in this study.

\section{References}

Berry, G., McKerrow, C. B., Molyneux, M. K. B., Rossiter, C. E., and Tombleson, J. B. L. (1973). A study of the acute and chronic changes in ventilatory capacity of workers in Lancashire cotton mills. British Journal of Industrial Medicine, 30, 25-36.

Boren, H. G., Kory, R. C., and Syner, J. C. (1966). The Veterans Administration-Army Cooperative Study of Pulmonary Function. II The lung volume and its subdivisions in normal men. American Journal of Medicine, 41, 96-114.

Bouhuys, A. and Lindell, S. E. (1961). Release of histamine by cotton dust extracts from human lung tissue in vitro. Experientia, 17, 211-215.

_- and Lundin, G. (1960). Experimental studies in byssinosis. British Medical Journal, 1, 324-326.

— and Nicholls, P. J. (1966). The effect of cotton dust on respiratory mechanics in man and in guinea pigs. Inhaled Particles and Vapours, edited by C. N. Davies, Vol. 2, pp. 75-85. Pergamon Press, New York. Wolfson, R. L., Horner, D. W., Brain, J. D., and Zuskin, E. (1969). Byssinosis in cotton textile workers -respiratory survey of a mill with rapid labour turnover. Annals of Internal Medicine, 71, 257-269.

Cavagna, G., Foa, V., and Vigliani, E. C. (1969). Effects in man and rabbits of inhalation of cotton dust or extracts and purified endotoxins. British Journal of Industrial Medicine, 26, 314-321.

Davenport, A. and Paton, W. D. M. (1962). The pharmacological activity of extracts of cotton dust. British Journal of Industrial Medicine, 19, 19-32.

Ferris, B. G., Jr., Anderson, D. O., and Zickmantel, R. (1965). Prediction values for screening tests of pulmonary function. American Review of Respiratory Diseases, 91, 252-261. 
Fox, A. J., Tombleson, J. B. L., Watt, A., and Wilkie, A. G. (1973). A survey of respiratory disease in cotton operatives. British Journal of Industrial Medicine, 30, 42-47.

Hedin, P. A., Thompson, A. C., and Gueldner, R. C. (1973). An investigation of essential oils of cotton mill dust. Annals of the New York Academy of Science (In press).

Hitchcock, M., Piscitelli, D. M., and Bouhuys, A. (1973). Histamine release from human lung by a component of cotton bracts. Archives of Environmental Health, 26, 177-182.

Imbus, H. R. and Suh, M. W. (1973). Byssinosis-a study of 10,133 textile workers. Archives of Environmental Health, 26, 183-191.

Kilburn, K. H., Lynn, W. S., Tres, L. L., and McKenzie, W. N. (1973). Leukocyte-rocruitment through airway walls by condensed vegetable tannins and quercetin. Laboratory Investigation, 28, 55-59.

Klein, F. K., Rapoport, H., and Elliott, H. W. (1971). Cannabis alkaloids. Nature, 232, 258-259.

Kory, R. C., Callahan, R., Boren, H. G., and Syner, S. C. (1961). Veterans Administration-Army Cooperative Study of Pulmonary Function. I. Clinical spirometry in normal men. American Journal of Medicine, 30, 243-258.

Lynch, J. R. (1970). Air sampling for cotton dust. Transactions of the National Conference on Cotton Dust and Health, pp. 33-43. University of North Carolina, Chapel Hill.

McKerrow, C. B., McDermott, M., Gilson, J. C., and Schilling, R. S. F. (1958). Respiratory function during the day in cotton workers: a study in byssinosis. British Journal of Industrial Medicine, 15, 75-83.

Merchant, J. A. (1970). Current status and studies of byssinosis in North Carolina. Transactions of the National Conference on Cotton Dust and Health, pp. 86-88A. University of North Carolina, Chapel Hill.

_, Kilburn, K. H., O'Fallon, W. M., Hamilton, J. D., and Lumsden, J. C. (1972). Byssinosis and chronic bronchitis among cotton textile workers. Annals of Internal Medicine, 76, 423-433.

_, Lumsden, J. C., Kilburn, K. H., Germino, V. H., Hamilton, J. D., Lynn, W. S., Byrd, H., and Baucom,
D. (1973a). Preprocessing cotton to prevent byssinosis. British Journal of Industrial Medicine, 30, 237-247.

——, - O'Fallon, W. M., Ujda, J. R., Germino, V. H., and Hamilton, J. D. (1973b). An industrial study of the biological effects of cotton dust and cigarette smoke exposure. Journal of Occupational Medicine, 15, 212-221. - - _ - - (1973c). Dose response studies in cotton textile workers. Journal of Occupational Medicine, 15, 222-230.

Molyneux, M. K. B. and Tombleson, J. B. L. (1970). An epidemiological study of respiratory symptoms in Lancashire mills, 1963-66. British Journal of Industrial Medicine, 27, 225-234.

MRC Committee on Aetiology of Chronic Bronchitis (1960). Standardized questionaries on respiratory symptoms. British Medical Journal, 2, 1665.

Nicholls, P. J., Nicholls, G. R., and Bouhuys, A. (1966). Histamine release by compound $48 / 80$ and textile dusts from lung tissue in vitro. Inhaled Particles and Vapours, edited by C. N. Davies, vol. 2, pp. 69-74. Pergamon Press, New York.

Roach, S. A. and Schilling, R. S. F. (1960). A clinical and environmental study of byssinosis in the Lancashire cotton industry. British Journal of Industrial Medicine, 17, 1-9.

Schilling, R. S. F., Vigliani, E. C., Lammers, B., Valic, F., and Gilson, J. C. (1964). A report on a conference on byssinosis. Proceedings of the XIVth International Congress on Industrial Health, Madrid, 1963, 2 137-145. Excerpta Medica Foundation, Amsterdam,

Schrag, P. E. and Gullet, A. D. (1970). Byssinosis in cotton textile mills. American Review of Respiratory Diseases, 101, 497-503.

Taylor, G., Massoud, A. A. E., and Lucas, F. (1971). Studies on the aetiology of byssinosis. British Journal of Industrial Medicine, 28, 143-151.

Zuskin, E., Wolfson, R. L., Harpel, G., Welborn, J. W., and Bouhuys, A. (1969). Byssinosis in carding and spinning workers. Archives of Environmental Health, 19, 666-673.

Received for publication 20 December, 1973.

Accepted for publication 25 March, 1974. 
APPENDIX 1

Mean Changes in FEV 1.0 over Six Hours of Exposure to Steamed and Unsteamed Cotton in Members of a Test Panel during Intervention Trials

\begin{tabular}{|c|c|c|c|c|c|c|c|c|}
\hline \multirow{2}{*}{ Steaming trial } & \multirow{2}{*}{$\begin{array}{l}\text { No. of } \\
\text { subjects }\end{array}$} & \multirow{2}{*}{$\begin{array}{l}\text { Steamed } \\
\text { cotton } \\
\Delta F E V_{1.0} \\
\quad(m l)\end{array}$} & \multicolumn{3}{|c|}{$\begin{array}{l}\text { First unsteamed } \\
\text { cotton control trial }\end{array}$} & \multicolumn{3}{|c|}{$\begin{array}{l}\text { Second unsteamed } \\
\text { cotton control trial }\end{array}$} \\
\hline & & & $\begin{array}{l}\Delta F E V_{1} \cdot 0 \\
(m l)\end{array}$ & $\begin{array}{l}\% \text { First } \\
\text { control } \\
\Delta F E V_{1.0}\end{array}$ & $\begin{array}{c}P \\
(m l)\end{array}$ & $\Delta F E V_{1 . \bullet}$ & $\begin{array}{l}\% \text { Second } \\
\text { control } \\
\Delta F E V_{1 . .}\end{array}$ & $P$ \\
\hline $\begin{array}{l}\text { Trial 1: } 15 \% \\
\text { steamed cotton } \\
\text { Adj. } 1 \mathrm{mg} / \mathrm{m}^{3}\end{array}$ & 58 & $\begin{array}{l}-254 \cdot 0 \\
-299 \cdot 2\end{array}$ & $\begin{array}{l}-182 \cdot 1 \\
-240 \cdot 5\end{array}$ & $\begin{array}{l}139 \cdot 5 \\
124 \cdot 4\end{array}$ & $<0.05$ & $\begin{array}{l}-177 \cdot 8 \\
-220 \cdot 5\end{array}$ & $\begin{array}{l}142 \cdot 9 \\
135 \cdot 7\end{array}$ & $<0.05$ \\
\hline $\begin{array}{l}\text { Trial 2: } 50 \% \\
\text { steamed cotton } \\
\text { Adj. } 1 \mathrm{mg} / \mathrm{m}^{3}\end{array}$ & 56 & $\begin{array}{l}-125 \cdot 2 \\
-197 \cdot 3\end{array}$ & $\begin{array}{l}-186 \cdot 5 \\
-243 \cdot 4\end{array}$ & $\begin{array}{l}67 \cdot 1 \\
81 \cdot 1\end{array}$ & $<0.05$ & $\begin{array}{l}-187 \cdot 3 \\
-224 \cdot 5\end{array}$ & $\begin{array}{l}66 \cdot 8 \\
87 \cdot 9\end{array}$ & $<0.01$ \\
\hline $\begin{array}{l}\text { Trial 3: } 75 \% \\
\text { steamed cotton } \\
\text { Adj. } 1 \mathrm{mg} / \mathrm{m}^{3}\end{array}$ & 48 & $\begin{array}{l}-141 \cdot 9 \\
-140 \cdot 3\end{array}$ & $\begin{array}{l}-193 \cdot 9 \\
-274 \cdot 3\end{array}$ & $\begin{array}{l}73 \cdot 2 \\
51 \cdot 1\end{array}$ & NS & $\begin{array}{l}-222 \cdot 2 \\
-283 \cdot 0\end{array}$ & $\begin{array}{l}63 \cdot 9 \\
49 \cdot 6\end{array}$ & $<0.01$ \\
\hline $\begin{array}{l}\text { Trial 4: } 100 \% \\
\text { steamed cotton } \\
\text { Adj. } 1 \mathrm{mg} / \mathrm{m}^{3}\end{array}$ & 52 & $\begin{array}{l}-173 \cdot 1 \\
-246 \cdot 4\end{array}$ & $\begin{array}{l}-183 \cdot 8 \\
-240 \cdot 5\end{array}$ & $\begin{array}{r}94 \cdot 2 \\
102 \cdot 5\end{array}$ & NS & $\begin{array}{l}-206 \cdot 6 \\
-253 \cdot 0\end{array}$ & $\begin{array}{l}83 \cdot 8 \\
97 \cdot 4\end{array}$ & NS \\
\hline $\begin{array}{l}\text { Trial 5: } 100 \% \\
\text { steamed cotton } \\
\text { Adj. } 1 \mathrm{mg} / \mathrm{m}^{3}\end{array}$ & 50 & $\begin{array}{l}-171 \cdot 8 \\
-240 \cdot 1\end{array}$ & $\begin{array}{l}-198 \cdot 7 \\
-278 \cdot 1\end{array}$ & $\begin{array}{l}86 \cdot 5 \\
86 \cdot 3\end{array}$ & NS & $\begin{array}{l}-210 \cdot 7 \\
-281 \cdot 8\end{array}$ & $\begin{array}{l}81 \cdot 5 \\
85 \cdot 2\end{array}$ & NS \\
\hline $\begin{array}{l}\text { Trial 6: } 100 \% \\
\text { steamed cotton } \\
\text { Adj. } 1 \mathrm{mg} / \mathrm{m}^{3}\end{array}$ & 51 & $\begin{array}{l}-107 \cdot 2 \\
-171 \cdot 4\end{array}$ & $\begin{array}{l}-200 \cdot 9 \\
-273 \cdot 0\end{array}$ & $\begin{array}{l}53 \cdot 4 \\
62 \cdot 8\end{array}$ & $<0.025$ & $\begin{array}{l}-213 \cdot 0 \\
-267 \cdot 9\end{array}$ & $\begin{array}{l}50 \cdot 3 \\
64 \cdot 0\end{array}$ & $<0.01$ \\
\hline $\begin{array}{l}\text { Trial 7: } 100 \% \\
\text { steamed cotton } \\
\text { Adj. } 1 \mathrm{mg} / \mathrm{m}^{3}\end{array}$ & 48 & $\begin{array}{l}-86 \cdot 3 \\
-131 \cdot 7\end{array}$ & $\begin{array}{l}-170 \cdot 8 \\
-273 \cdot 6\end{array}$ & $\begin{array}{l}50 \cdot 5 \\
48 \cdot 1\end{array}$ & $<0.025$ & $\begin{array}{l}-191 \cdot 6 \\
-270 \cdot 2\end{array}$ & $\begin{array}{l}45 \cdot 0 \\
48 \cdot 7\end{array}$ & $<0.01$ \\
\hline $\begin{array}{l}\text { Trial } 8: 100 \% \\
\text { steamed cotton } \\
\text { Adj. } 1 \mathrm{mg} / \mathrm{m}^{3}\end{array}$ & 43 & $\begin{array}{l}-134 \cdot 3 \\
-173 \cdot 3\end{array}$ & $\begin{array}{l}-233 \cdot 3 \\
-302 \cdot 2\end{array}$ & $\begin{array}{l}57 \cdot 6 \\
57 \cdot 3\end{array}$ & $<0.025$ & $\begin{array}{l}-245 \cdot 6 \\
-301 \cdot 3\end{array}$ & $\begin{array}{l}54 \cdot 7 \\
57 \cdot 5\end{array}$ & $<0.01$ \\
\hline $\begin{array}{l}\text { Trial 9: } 100 \% \\
\text { steamed cotton } \\
\text { Adj. } 1 \mathrm{mg} / \mathrm{m}^{3}\end{array}$ & 38 & $\begin{array}{l}-76 \cdot 3 \\
-86 \cdot 5\end{array}$ & $\begin{array}{l}-208 \cdot 3 \\
-248 \cdot 8\end{array}$ & $\begin{array}{l}36 \cdot 6 \\
34 \cdot 8\end{array}$ & $<0.01$ & $\begin{array}{l}-218 \cdot 0 \\
-264 \cdot 7\end{array}$ & $\begin{array}{l}35 \cdot 0 \\
32 \cdot 7\end{array}$ & $<0.005$ \\
\hline
\end{tabular}

$1800 \mathrm{lb} / \mathrm{hr} ; 2950 \mathrm{lb} / \mathrm{hr}$ 
APPENDIX 2

Median Dust Levels $\left(\mathrm{mg} / \mathrm{m}^{3}\right.$ ) and Percent Change in Dust Levels during Steaming INTERVENTION TRIALS: CONTROL Trials

\begin{tabular}{|c|c|c|c|c|c|c|c|c|c|c|}
\hline & $\begin{array}{c}\text { No } \\
\text { steamed } \\
\text { cotton }\end{array}$ & $\begin{array}{c}\text { Trial 1 } \\
15 \% \\
\text { steamed } \\
\text { cotton }\end{array}$ & $\begin{array}{c}\text { Trial } 2 \\
50 \% \\
\text { steamed } \\
\text { cotton }\end{array}$ & $\begin{array}{c}\text { Trial } 3 \\
75 \% \\
\text { steamed } \\
\text { cotton }\end{array}$ & $\begin{array}{c}\text { Trial } 4 \\
100 \% \\
\text { steamed } \\
\text { cotton }\end{array}$ & $\begin{array}{c}\text { Trial } 5 \\
100 \% \\
\text { steamed } \\
\text { cotton }\end{array}$ & $\begin{array}{c}\text { Trial } 6 \\
100 \% \\
\text { steamed } \\
\text { cotton }\end{array}$ & $\begin{array}{c}\text { Trial } 7 \\
100 \% \\
\text { steamed } \\
\text { cotton }\end{array}$ & $\begin{array}{c}\text { Trial } 8 \\
100 \% \\
\text { steamed } \\
\text { cotton }\end{array}$ & $\begin{array}{c}\text { Trial } 9 \\
100 \% \\
\text { steamed } \\
\text { cotton }\end{array}$ \\
\hline $\begin{array}{l}\text { Blending } \\
\text { n } \\
\text { Median } \\
\% \\
\text { Opening }\end{array}$ & $\begin{array}{l}23 \\
4 \cdot 57 \\
-\end{array}$ & $\begin{array}{r}11 \\
\quad 3 \cdot 20 \\
-30 \cdot 0\end{array}$ & $\begin{array}{c}12 \\
3 \cdot 31 \\
-27 \cdot 6\end{array}$ & $\begin{array}{c}6 \\
2 \cdot 62 \\
-42 \cdot 7\end{array}$ & $\begin{array}{c}12 \\
2 \cdot 10 \\
-54 \cdot 0\end{array}$ & $\begin{array}{c}12 \\
2.03 \\
-55.6\end{array}$ & $\begin{array}{c}9 \\
1 \cdot 23 \\
-73 \cdot 1\end{array}$ & $\begin{array}{c}10 \\
3 \cdot 17 \\
-30 \cdot 6\end{array}$ & $\begin{array}{c}10 \\
1 \cdot 80 \\
-60 \cdot 6\end{array}$ & $\begin{array}{c}11 \\
2 \cdot 18 \\
-52 \cdot 3\end{array}$ \\
\hline $\begin{array}{l}\text { n } \\
\text { Median } \\
\% \\
\text { Picking }\end{array}$ & $\begin{array}{l}21 \\
3 \cdot 18 \\
-\end{array}$ & $\begin{array}{c}12 \\
3 \cdot 05 \\
-4 \cdot 1\end{array}$ & $\begin{array}{c}12 \\
1.91 \\
-39.9\end{array}$ & $\begin{array}{c}12 \\
2 \cdot 36 \\
-25 \cdot 8\end{array}$ & $\begin{array}{c}12 \\
2 \cdot 28 \\
-28 \cdot 3\end{array}$ & $\begin{array}{c}12 \\
2 \cdot 36 \\
-25 \cdot 8\end{array}$ & $\begin{array}{c}11 \\
2 \cdot 16 \\
-32 \cdot 1\end{array}$ & $\begin{array}{c}12 \\
2 \cdot 82 \\
-11 \cdot 3\end{array}$ & $\begin{array}{c}12 \\
2 \cdot 32 \\
-27 \cdot 0\end{array}$ & $\begin{array}{c}12 \\
2 \cdot 05 \\
-35 \cdot 5\end{array}$ \\
\hline $\begin{array}{l}\text { n } \\
\text { Median } \\
\% \\
\text { Carding }\end{array}$ & $\begin{array}{l}24 \\
3 \cdot 75 \\
-\end{array}$ & $\begin{array}{c}12 \\
4.96 \\
+32.3\end{array}$ & $\begin{array}{c}12 \\
4 \cdot 27 \\
+13 \cdot 9\end{array}$ & $\begin{array}{c}12 \\
4.50 \\
+20 \cdot 0\end{array}$ & $\begin{array}{c}12 \\
2 \cdot 49 \\
-33 \cdot 6\end{array}$ & $\begin{array}{c}12 \\
2 \cdot 38 \\
-36 \cdot 5\end{array}$ & $\begin{array}{c}9 \\
3 \cdot 14 \\
-16 \cdot 3\end{array}$ & $\begin{array}{c}12 \\
3 \cdot 48 \\
-7 \cdot 2\end{array}$ & $\begin{array}{c}12 \\
2 \cdot 25 \\
-40 \cdot 0\end{array}$ & $\begin{array}{c}12 \\
2 \cdot 59 \\
-30 \cdot 9\end{array}$ \\
\hline $\begin{array}{l}\text { n } \\
\text { Median } \\
\text { \% } \\
\text { Drawing }\end{array}$ & $\begin{array}{l}68 \\
0.77 \\
-\end{array}$ & $\begin{array}{c}35 \\
0.93 \\
+20.8\end{array}$ & $\begin{array}{c}34 \\
0 \cdot 70 \\
-9 \cdot 1\end{array}$ & $\begin{array}{c}34 \\
0.93 \\
+20.8\end{array}$ & $\begin{array}{c}35 \\
0.82 \\
+6.5\end{array}$ & $\begin{array}{c}36 \\
0.75 \\
-2.6\end{array}$ & $\begin{array}{c}33 \\
0.58 \\
-24 \cdot 7\end{array}$ & $\begin{array}{c}36 \\
0.96 \\
+24.7\end{array}$ & $\begin{array}{c}35 \\
0.91 \\
+18 \cdot 2\end{array}$ & $\begin{array}{c}36 \\
1 \cdot 17 \\
+51.9\end{array}$ \\
\hline $\begin{array}{l}\text { n } \\
\text { Median } \\
\% \\
\text { Roving }\end{array}$ & $\begin{array}{l}24 \\
0.62 \\
-\end{array}$ & $\begin{array}{c}12 \\
0.71 \\
+12 \cdot 7\end{array}$ & $\begin{array}{c}11 \\
0.52 \\
-17.5\end{array}$ & $\begin{array}{c}12 \\
0.59 \\
-6.3\end{array}$ & $\begin{array}{c}12 \\
0 \cdot 50 \\
-20 \cdot 6\end{array}$ & $\begin{array}{c}12 \\
0.57 \\
-9.5\end{array}$ & $\begin{array}{c}10 \\
0.44 \\
-30 \cdot 2\end{array}$ & $\begin{array}{c}12 \\
0.64 \\
+1.6\end{array}$ & $\begin{array}{c}12 \\
0.64 \\
+1.6\end{array}$ & $\begin{array}{c}11 \\
0.75 \\
+19.0\end{array}$ \\
\hline $\begin{array}{l}\text { n } \\
\text { Median } \\
\% \\
\text { Spinning }\end{array}$ & $\begin{array}{c}24 \\
0 \cdot 39 \\
-\end{array}$ & $\begin{array}{c}8 \\
0.53 \\
+35.9\end{array}$ & $\begin{array}{c}12 \\
0.41 \\
+5 \cdot 1\end{array}$ & $\begin{array}{c}12 \\
0.49 \\
+25.6\end{array}$ & $\begin{array}{c}12 \\
0.48 \\
+23.0\end{array}$ & $\begin{array}{c}11 \\
0.44 \\
+12.8\end{array}$ & $\begin{array}{c}11 \\
0.42 \\
+7 \cdot 7\end{array}$ & $\begin{array}{c}12 \\
0.47 \\
+20.5\end{array}$ & $\begin{array}{c}12 \\
0.61 \\
+56.4\end{array}$ & $\begin{array}{c}11 \\
0.71 \\
+82 \cdot 1\end{array}$ \\
\hline $\begin{array}{c}\mathrm{n} \\
\text { Median } \\
\% \\
\text { Winding \& }\end{array}$ & $\begin{array}{c}60 \\
0.39 \\
\text { twisting }\end{array}$ & $\begin{array}{r}27 \\
0.46 \\
+17.9\end{array}$ & $\begin{array}{c}18 \\
0.35 \\
-10 \cdot 3\end{array}$ & $\begin{array}{c}27 \\
0.50 \\
+28.2\end{array}$ & $\begin{array}{c}24 \\
0.51 \\
+30.8\end{array}$ & $\begin{array}{c}24 \\
0.50 \\
+28 \cdot 2\end{array}$ & $\begin{array}{l}29 \\
0.42 \\
+7 \cdot 7\end{array}$ & $\begin{array}{c}30 \\
0.49 \\
+25.6\end{array}$ & $\begin{array}{c}28 \\
0.59 \\
+51.3\end{array}$ & $\begin{array}{c}30 \\
0.62 \\
+59.0\end{array}$ \\
\hline $\begin{array}{c}\text { n } \\
\text { Median } \\
\% \\
\text { Total }\end{array}$ & $\begin{array}{c}48 \\
0.56 \\
-\end{array}$ & $\begin{array}{c}22 \\
0 \cdot 48 \\
-14 \cdot 3\end{array}$ & $\begin{array}{c}23 \\
0.40 \\
-28.6\end{array}$ & $\begin{array}{c}24 \\
0.54 \\
-3.6\end{array}$ & $\begin{array}{c}24 \\
0.39 \\
-30.4\end{array}$ & $\begin{array}{l}23 \\
0 \cdot 51 \\
-8 \cdot 9\end{array}$ & $\begin{array}{c}24 \\
0.47 \\
-16 \cdot 1\end{array}$ & $\begin{array}{c}24 \\
0.49 \\
-12.5\end{array}$ & $\begin{array}{c}24 \\
0 \cdot 70 \\
+25 \cdot 0\end{array}$ & $\begin{array}{c}24 \\
0.66 \\
+17.9\end{array}$ \\
\hline $\begin{array}{l}\text { Median } \\
\%\end{array}$ & $\begin{array}{c}292 \\
0.64 \\
-\end{array}$ & $\begin{array}{c}140 \\
0.70 \\
+9.4\end{array}$ & $\begin{array}{c}134 \\
0.57 \\
-10.9\end{array}$ & $\begin{array}{r}139 \\
0.65 \\
+1.6\end{array}$ & $\begin{array}{c}143 \\
0.63 \\
-1.6\end{array}$ & $\begin{array}{r}142 \\
0.65 \\
+1.6\end{array}$ & $\begin{array}{c}126 \\
0.51 \\
-20.3\end{array}$ & $\begin{array}{r}138 \\
0.70 \\
+9.4\end{array}$ & $\begin{array}{c}145 \\
0.82 \\
+28 \cdot 1\end{array}$ & $\begin{array}{c}147 \\
0.85 \\
+32.8\end{array}$ \\
\hline
\end{tabular}

$1800 \mathrm{lb} / \mathrm{hr} ; 2950 \mathrm{lb} / \mathrm{hr}$ 